\title{
The Effects of Urban Farming on Well-Being of the Elderly: A Focus on Social, Psychological, and Environmental Well-Being
}

\author{
Ji-Hye Yang and Min-Hwan Na
}

\begin{abstract}
This study examines the effect of urban farming on the well-being of the elderly, and with a focus on the effect of participation in urban farming on psychological well-being, and the mediating effects of social well-being and environmental well-being on that relationship. We surveyed individuals aged 55 or older residing in the Gyeonggi or Busan regions to measure their social well-being, psychological wellbeing, and environmental well-being. We conducted t-tests, correlation analyses, and regression analyses on a sample of 385 individuals, and our results were as follows. First, people who participated in urban farming reported a significantly higher level of social, psychological, and environmental wellbeing than those who did not. Second, social, psychological, and environmental well-being were related to each other in a statistically-significant way. However, age and well-being revealed a statistically negative relationship, as did the relationship between satisfaction with economic conditions and well-being. Third, our testing of mediating effects found that, regarding the effect of participation in urban farming on psychological well-being, social well-being was a complete mediator while environmental well-being was a partial mediator. These results suggest that urban farming enhances the well-being of the elderly, and the expansion of urban farming can be a viable component of improving welfare for the elderly. This study is also meaningful in that it investigates the social effects of urban farming, a topic that existing studies have not examined in depth.
\end{abstract}

Index Terms-Urban farming, the elderly, psychological well-being, social well-being, environmental well-being.

\section{Definition of Problem AND PuRPose of Study}

Due to rapid industrialization and urbanization, Korea's urbanization rate has increased exponentially from $39.1 \%$ in 1960 , to $79.6 \%$ in 1990 , and $90 \%$ in 2012 . As a result, various urban problems, such as urban environmental problems and the breakup of local communities, have emerged [1]. There is a wide range of modern urban problems, including the urban heat island phenomenon caused by excessive emission of carbon dioxide, and the damaging of natural scenery and green spaces within cities due to indiscriminate development plans. Modern urban problems also include lack of opportunity for urban residents to enjoy leisure activities and nature and social polarization among urban residents. Urban farming is emerging as an alternative that can help resolve such urban problems, and numerous countries around the world are developing urban farming in various forms.

Manuscript received June 21, 2016; revised September 12, 2016.

The authors are with the Hanguk Academy of Foreign Studies, Yongin, South Korea (e-mail: jenniferyjh@naver.com, shawn0813@naver.com).
Some countries in Europe, including Germany and the UK, are continuing urban farming efforts that had already been systematized in the late 19th or early 20th centuries, and even today, institutional mechanisms are in place to promote urban farming. In Germany, urban green areas called Kleingarten were created in the early days of industrialization, and the government or public institutions rented idle land cheaply to the petit bourgeoisie so they could maintain health and foster emotional well-being through the activity of farming [2]. The UK has an allotment system that provides empty land in the city to individual citizens or local communities at low prices, allowing them to grow food and enjoy wholesome leisure activities, and experience social interaction [3].

Urban farming has recently garnered attention because it can help develop local communities and improve social harmony, and create a beautiful and comfortable cityscape; it is also hoped that it can provide eco-friendly food to city dwellers [4]. In addition, urban farming is highly valuable environmentally, economically, and socially. The economic functions of urban farming include: consumption of selfmade produce, social interaction, reduction of urban environmental costs, social functions such as experience, education, rest, and healing, and ecological functions such as the conservation of the urban environment [5].

In this way, studies on the multiple effects of urban farming have been actively conducted. However, most of them tend to focus on the environmental aspects, while studies on the social effects have been relatively lacking. In addition, almost no empirical analysis has been conducted on whether urban farming can be a tool for cultivating the emotions of city dwellers. Therefore, considering that Korea has an aging population, this study looks at a social effect of urban farming that other studies have not addressed by empirically investigating whether urban farming enhances the well-being of the elderly.

With this goal, we surveyed a sample of elderly persons to see whether they participated in urban farming, and measured their social, psychological, and environmental well-being. First, we analyzed the differences in social, psychological, and environmental well-being between urban farming participants and nonparticipants. Next, we analyzed the relationship between each factor to discover the relationship between age and well-being, the relationship between satisfaction with one's economic conditions and well-being, and the correlation between each type of wellbeing. Finally, we investigated whether environmental wellbeing and social well-being mediate the effect of participation in urban farming on psychological well-being. 


\section{SubJeCtS AND Methodology}

\section{A. Subjects}

This study surveyed elderly individuals aged 55 or older from across the country. Among a total of 400 individuals who participated in the survey, 15 were excluded as they were seen to have responded insincerely. We conducted ttests, correlation analyses, and mediation analyses on the remaining 385 participants. Among 385 subjects, 191 (49.6\%) participated in urban farming, and 194 (50.4\%) did not participate. Males were slightly outnumbered by females in the sample with $172(44.7 \%)$ males and $213(55.3 \%)$ females. Regarding satisfaction with their economic conditions - which could affect the respondents' well-being $-17(4.4 \%)$ were very satisfied, $129(33.5 \%)$ were satisfied, $191(49.6 \%)$ were neutral, $40(10.4 \%)$ were dissatisfied, and seven $(1.8 \%)$ were very dissatisfied. The mean age of participants was 64.7 .

\section{B. Measuring Data}

\section{1) Social well-being}

Lim, Ko, Shin, and Cho [6] used a scale for measuring the happiness and mental health of Koreans. The scale measures the mental health of Koreans and consists of 14 questions. From these questions, we extracted and used five questions for our survey that were related to social well-being. We measured the social well-being of survey participants by asking them to express the feelings they felt during the past month on a six-point Likert scale (never, one or two times a month, once a week, two or three times a week, almost daily, daily). The Cronbach's alpha for the scale used to measure social well-being in this study was 0.85 .

\section{2) Psychological well-being}

From the Lim, Ko, Shin, and Cho [6] scale, we extracted and used three questions related to emotional well-being and six questions related to psychological well-being. We used a six-point Likert scale (never, one or two times a month, once a week, two or three times a week, almost daily, daily) to measure the survey participants' emotional and psychological well-being. The Cronbach's alpha was 0.93 .

\section{3) Environmental well-being}

We reorganized the Four-Item Naturalness Scale developed by Keyes [7] to use in this study. This scale is a tool originally developed to identify quality of the living environment and individual mental health, and consists of three specific items. It asks questions about the natural scenery viewable from windows, the number of plants and trees in the house, and the materials used in the yard, and includes four examples to induce respondents to answer. In our survey, we took the three questions proposed by Keyes and revised them to measure the participants' environmental well-being. The Cronbach's alpha was 0.9.

\section{Analyzing Data}

To discover the relationship between social well-being, psychological well-being, and environmental well-being, we performed a correlation analysis between the variables. To confirm the mediating effect of social well-being and environmental well-being on improved psychological wellbeing due to participation in urban farming, we conducted a regression analysis based on the standards below proposed by Baron and Kenny [8].

Baron and Kenny stated that for a mediating effect to exist, 1) in stage one, the independent variable must have a significant effect on the mediating variable, 2) in stage two, the independent variable must have a significant effect on the dependent variable, 3) in stage three, while the effect of the independent variable on the dependent variable is being controlled, the mediating variable must have a significant effect on the dependent variable, and 4) the effect of the independent variable on dependent variables in the regression equation (including the mediating variable) must be smaller than in condition 2), or be nonexistent. If the effect was smaller, it means that the mediating effect was partial, and if it was nonexistent, it means that the mediating effect was total.

\section{RESUltS OF STUDY}

\section{A. Differences in Well-Being According to Participation in Urban Farming}

We conducted t-tests to discover whether participation in urban farming resulted in different levels of psychological, social, and environmental well-being. The results, shown in Table I, indicate that participants reported having a significantly higher average psychological well-being $(t=$ $3.58, p<.01)$, social well-being $(t=4.35, p<.01)$, and environmental well-being $(t=2.28, p<.02)$ than nonparticipants.

\section{B. Correlation between Major Variables}

We performed a correlation analysis to discover the correlation between the major variables. The results, shown in Table II, indicated a significant negative relationship between age and living expenses $(r=-.36, p<.01)$, while the relationships between age and satisfaction with economic conditions, and age and perception of economic conditions were not significant. In addition, the relationships between age and period of participation $(r=.31, p<.01)$, and age and frequency of participation $(r=.32, p<.01)$, were statistically significant. However, the relationships between age and environmental well-being $(r=-.11, p$ $<.05)$, social well-being $(r=-.14, p<.01)$, and psychological well-being $(r=-.12, p<.05)$ were all negatively significant.

Regarding the relationship between satisfaction with economic conditions and each variable, the relationships between satisfaction with economic conditions and psychological well-being $(r=-.36, p<.01)$, social wellbeing $(r=-.28, p<.01)$, and environmental well-being $(r=-$ $.38, p<.01)$ were all negatively significant. However, the relationships between satisfaction with economic conditions and period of participation and frequency of participation were not significant. The relationships of period of participation and frequency of participation to environmental well-being, social well-being, and psychological well-being were not found to be significant.

Regarding the relationships between psychological wellbeing, social well-being, and environmental well-being, the relationship between environmental well-being and psychological well-being was statistically significant $(r$ $=.39, p<.01)$, as was the relationship between 
environmental well-being and social well-being $(r=.37, p \quad$ and social well-being showed the same tendency $(\mathrm{r}=.80, \mathrm{p}$ $<.01)$. The relationship between psychological well-being $<.01$

TABLE I: DIFFERENCES IN WELL-BEING ACCORDING TO PARTICIPATION IN URBAN FARMING

\begin{tabular}{|c|c|c|c|c|c|c|}
\hline & \multicolumn{2}{|c|}{ Participation } & \multicolumn{2}{|c|}{ Nonparticipation } & \multirow{2}{*}{$\mathrm{T}$} & \multirow{2}{*}{$\mathrm{p}$} \\
\hline & Average & Std. dev. & Average & Std. dev. & & \\
\hline $\begin{array}{l}\text { Psychological well- } \\
\text { being }\end{array}$ & 3.34 & .98 & 2.96 & 1.09 & $3.58^{* *}$ & .00 \\
\hline Social well-being & 3.14 & 1.01 & 2.69 & .97 & $4.35^{* *}$ & .00 \\
\hline $\begin{array}{l}\text { Environmental well- } \\
\text { being }\end{array}$ & 3.62 & .72 & 3.44 & .75 & $2.28^{*}$ & .02 \\
\hline
\end{tabular}

TABLE II: RESULTS OF ANALYSIS OF RELATIONSHIP BETWEEN MAIN VARIABLES

\begin{tabular}{|c|c|c|c|c|c|c|c|c|c|c|}
\hline & Age & $\begin{array}{l}\text { Educati } \\
\text { on }\end{array}$ & $\begin{array}{l}\text { Living } \\
\text { Expense } \\
\mathrm{s}\end{array}$ & $\begin{array}{l}\text { Satisfact } \\
\text { ion with } \\
\text { Econom } \\
\text { ic } \\
\text { Conditio } \\
\text { ns }\end{array}$ & $\begin{array}{l}\text { Awaren } \\
\text { ess of } \\
\text { Econom } \\
\text { ic } \\
\text { Conditio } \\
\text { ns }\end{array}$ & $\begin{array}{l}\text { Particip } \\
\text { ation } \\
\text { Period }\end{array}$ & $\begin{array}{l}\text { Particip } \\
\text { ation } \\
\text { Frequen } \\
\text { cy }\end{array}$ & $\begin{array}{l}\text { Psychol } \\
\text { ogical } \\
\text { Well- } \\
\text { being }\end{array}$ & $\begin{array}{l}\text { Social } \\
\text { Well- } \\
\text { being }\end{array}$ & $\begin{array}{l}\text { Environm } \\
\text { ental } \\
\text { Well- } \\
\text { being }\end{array}$ \\
\hline Age & 1 & & & & & & & & & \\
\hline Education & $-.46^{* *}$ & 1 & & & & & & & & \\
\hline Living Expenses & $-.36^{* *}$ & $.51^{* *}$ & 1 & & & & & & & \\
\hline $\begin{array}{l}\text { Satisfaction with } \\
\text { Economic } \\
\text { Conditions }\end{array}$ & .04 & $-.18^{* *}$ & $-.32^{* * *}$ & 1 & & & & & & \\
\hline $\begin{array}{l}\text { Awareness of } \\
\text { Economic } \\
\text { Conditions }\end{array}$ & -.03 & $.18^{* *}$ & $.36^{* *}$ & $-.64^{* *}$ & 1 & & & & & \\
\hline Participation Period & $.31^{* *}$ & $-.25^{* *}$ & -.14 & .014 & .06 & 1 & & & & \\
\hline $\begin{array}{l}\text { Participation } \\
\text { Frequency }\end{array}$ & $.32^{* *}$ & $-.42^{* *}$ & $-.24^{* *}$ & .036 & -.09 & $.34^{* *}$ & 1 & & & \\
\hline $\begin{array}{l}\text { Psychological Well- } \\
\text { being }\end{array}$ & $-.12^{*}$ & $.48^{* *}$ & $.38^{* *}$ & $-.36^{* *}$ & $.35^{* *}$ & .04 & .01 & 1 & & \\
\hline Social Well-being & $-.14^{* * *}$ & $.40^{* *}$ & $.34^{* *}$ & $-.28^{* * *}$ & $.26^{* *}$ & .08 & -.03 & $.80^{* *}$ & 1 & \\
\hline $\begin{array}{l}\text { Environmental } \\
\text { Well-being }\end{array}$ & $-.11^{*}$ & $.34^{* *}$ & $.30^{* *}$ & $-.38^{* *}$ & $.35^{* *}$ & -.07 & -.04 & $.39^{* *}$ & $.37^{* *}$ & 1 \\
\hline
\end{tabular}

\section{Mediating Effect of Social Well-Being and Environmental Well-Being}

\section{1) Mediating effect of social well-being}

To discover whether the relationship between participation in urban farming and psychological wellbeing was mediated by social well-being, we used the Baron and Kenny [8] method. The results, shown in Table III, indicate the following. In stage one, participation was set as the independent variable and social well-being, the mediating variable, was entered into the regression equation as a dependent variable. Participation was found to have a significant effect on social well-being $(\beta=.22, p$ $<.01$ ), and in the regression equation that had psychological well-being as the dependent variable, participation also had a significant effect $(\beta=.18, p<.01)$.

We conducted a Sobel test to confirm the statistical significance of this mediating effect, and found that social well-being had a significant mediating effect on the relationship between participation in urban farming and psychological well-being $(Z=3.55, p<.01)$.
Finally, to predict the effect of participation on psychological well-being, we used a regression equation with participation and social well-being as independent variables and psychological well-being as a dependent variable, and found that social well-being had a significant effect on psychological well-being $(\beta=.80, p$ $<.01)$. Here, the effect of participation on psychological well-being was not significant, so the mediating effect is complete.

Therefore, as summarized in Fig. 1, we found that social well-being was a full mediator in the relationship between participation in urban farming and psychological well-being.

\section{2) Mediating effect of environmental well-being}

To discover the effect that participation has on psychological well-being with environmental well-being as a mediator, we tested the mediating effect. In stage one, participation was set as the independent variable and social well-being, the mediating variable, was entered into the regression equation as a dependent variable. Participation was found to have a significant effect on 
environmental well-being $(\beta=.12, p<.05)$, and in the regression equation that had psychological well-being asthe dependent variable, participation also had a significant effect $(\beta=.18, p<.01)$.

Finally, we used a regression equation with participation and environmental well-being as independent variables and psychological well-being as the dependent variable, and found that the effect of participation on psychological well-being $(\beta=.14, p<.01)$ and the effect of environmental well-being on psychological well-being $(\beta=.37, p<.01)$ were both statistically significant. Compared to when participation was the only independent variable, the influence was smaller $(\beta=.14, p<.18)$ when environmental well-bein was also included. We can interpret this to mean that environmental well-being has a partial mediating effect on the relationship between participation in urban farming and psychological well-being.

TABLE III: Results of TeSting Mediating EFFeCt of Social WeLl-Being

\begin{tabular}{|c|c|c|c|c|c|c|c|c|}
\hline & $\begin{array}{l}\text { Dependent } \\
\text { Variable }\end{array}$ & $\begin{array}{l}\text { Independent } \\
\text { Variable }\end{array}$ & $B$ & StandardEnor & $\beta$ & $T$ & $R^{2}$ & $F$ \\
\hline Stage 1 & $\begin{array}{l}\text { Social Well- } \\
\text { being }\end{array}$ & $\begin{array}{l}\text { Participation/N } \\
\text { onparticipation }\end{array}$ & .44 & .10 & .22 & $4.35^{* *}$ & .05 & $18.95^{* *}$ \\
\hline Stage 2 & $\begin{array}{l}\text { Psychological } \\
\text { Well-being }\end{array}$ & $\begin{array}{l}\text { Participation/N } \\
\text { onparticipation }\end{array}$ & .38 & .11 & .18 & $3.58^{* *}$ & .03 & $12.82^{* *}$ \\
\hline \multirow{2}{*}{ Stage 3} & \multirow{2}{*}{$\begin{array}{l}\text { Psychological Well- } \\
\text { being }\end{array}$} & $\begin{array}{l}\text { Participation/Nonp } \\
\text { articipation }\end{array}$ & .01 & .07 & .01 & .19 & \multirow{2}{*}{.64} & \multirow{2}{*}{$345.03^{* *}$} \\
\hline & & Social Well-being & .83 & .03 & .80 & $25.60^{* *}$ & & \\
\hline
\end{tabular}

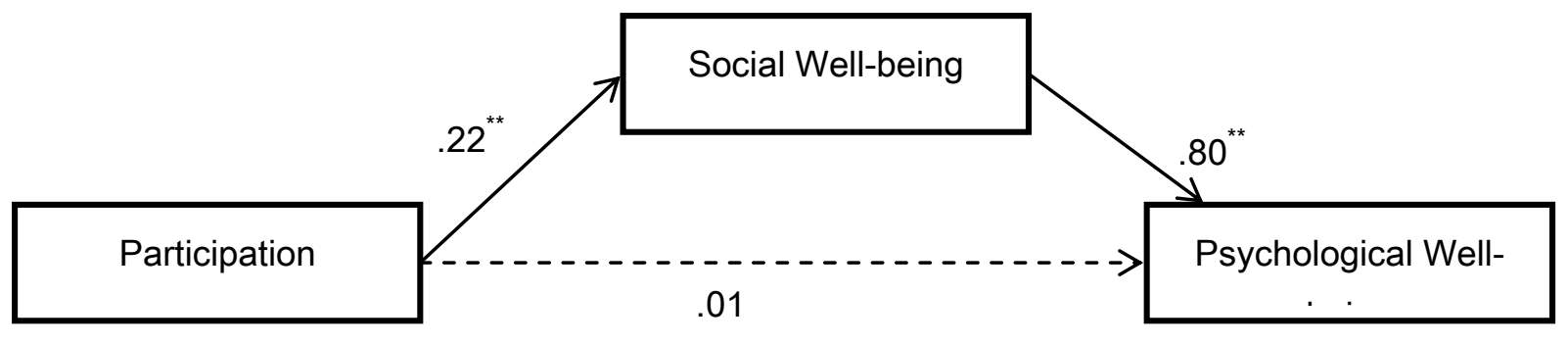

$\left(.18^{* *}\right)$

Fig. 1. Mediating effect of social well-being.

Next, we conducted a Sobel test to confirm the statistical significance of this mediating effect, and found that social well-being had a significant mediating effect on the relationship between participation in urban farming and psychological well-being $(\mathrm{Z}=3.27, \mathrm{p}<.01)$. Therefore, environmental well-being was shown to have a partial mediating effect on the relationship between participation in urban farming and psychological wellbeing. These results are summarized in Fig. 2 below.

\section{INTERPRETATION AND DISCUSSION OF RESULTS}

We summarize the study's results and discussion as follows. First, a t-test of the average difference in wellbeing between urban farming participants and nonparticipants found that participants had higher social, psychological, and environmental well-being than nonparticipants. Therefore, the study confirmed that urban farming enhances participants' well-being and this can support arguments for increasing opportunities for urban farming.

The analysis of the correlations between the main variables found that the relationship between age and psychological, social, and environmental well-being showed a significantly negative correlation, and the relationships between satisfaction with one's economic condition and psychological, social, and environmental well-being were also negatively significant. These statistical results show that, in general, life satisfaction and mental health decline with age. In addition, the negative correlation between satisfaction with one's economic condition and each type of well-being indicates that being well-off financially is unrelated to life satisfaction and mental health. These results contradict the conventional idea that wealthier elderly persons have greater life satisfaction, and suggest that emotional stability is just as important as economic stability in pursuing welfare for an aging society.

From analyzing the mediating effects between each type of well-being, we found the following results. First, participation was completely mediated by social wellbeing in affecting psychological well-being. This result supports previous studies that revealed that urban farming played an important role in forming the culture of family communities and neighborhood communities [9]. This demonstrates that a sense of social stability is a precondition of psychological well-being, and that the 
reason that participants in urban farming are more stable emotionally and psychologically is that participation in farming strengthens communities through social interaction. Second, it was shown that participation was partially mediated by environmental well-being, affecting psychological well-being. This meant that environmental satisfaction is a part of psychological satisfaction, and suggests that because participants in urban farming are more frequently exposed to the natural environment than nonparticipants, they experience greater environmental satisfaction, which can lead to increased psychological satisfaction.

\begin{tabular}{|c|c|c|c|c|c|c|c|c|}
\hline & $\begin{array}{l}\text { Dependent } \\
\text { Variable }\end{array}$ & $\begin{array}{l}\text { Independent } \\
\text { Variable }\end{array}$ & $B$ & $\begin{array}{l}\text { Standard } \\
\text { Enor }\end{array}$ & $\beta$ & $T$ & $R^{2}$ & $F$ \\
\hline $\begin{array}{l}\text { Stage } \\
1\end{array}$ & $\begin{array}{l}\text { Environmental } \\
\text { Well-being }\end{array}$ & $\begin{array}{r}\text { Participation/ } \\
\text { Nonparticipation }\end{array}$ & .17 & .07 & .12 & $2.28^{*}$ & .01 & $5.20^{* *}$ \\
\hline $\begin{array}{l}\text { Stage } \\
2\end{array}$ & $\begin{array}{l}\text { Psychological } \\
\text { Well-being }\end{array}$ & $\begin{array}{r}\text { Participation/ } \\
\text { Nonparticipation }\end{array}$ & .38 & .11 & .18 & $3.58^{* * *}$ & .03 & $12.82^{* * *}$ \\
\hline \multirow{2}{*}{$\begin{array}{l}\text { Stage } \\
3\end{array}$} & \multirow{2}{*}{$\begin{array}{l}\text { Psychological } \\
\text { Well-being }\end{array}$} & $\begin{array}{r}\text { Participation/ } \\
\text { Nonparticipation }\end{array}$ & .29 & .10 & .14 & $2.91^{* *}$ & \multirow{2}{*}{.17} & \multirow{2}{*}{$39.21^{* *}$} \\
\hline & & $\begin{array}{l}\text { Environmental } \\
\text { Well-being }\end{array}$ & .53 & .07 & .37 & $7.97^{* * *}$ & & \\
\hline
\end{tabular}

$* p<.05, * * p<.01$

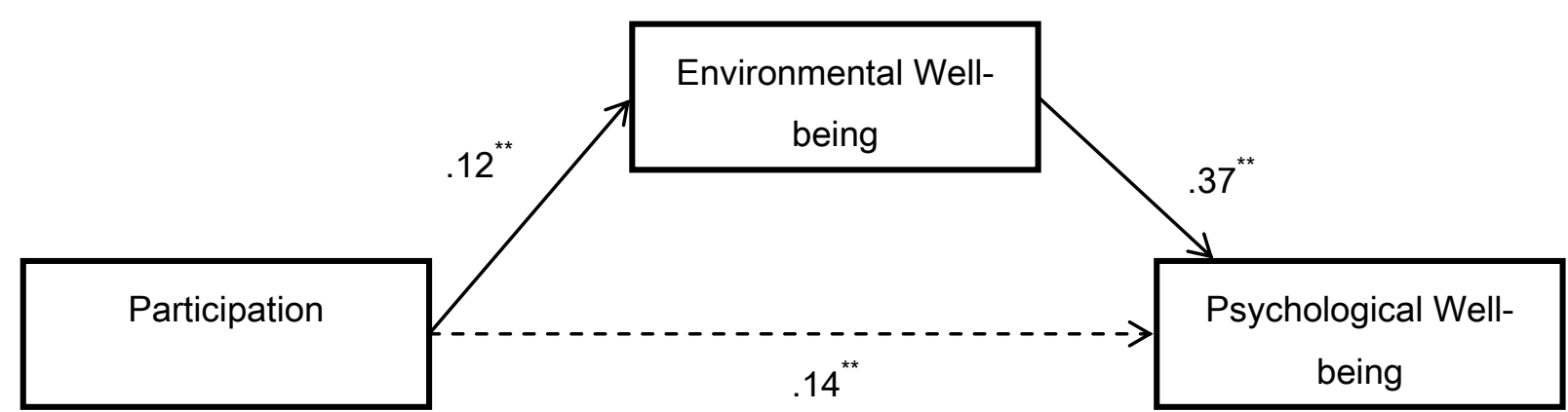

$\left(.18^{* *}\right)$

Fig. 2. Mediating effect of environmental well-being.

The study summarized above is meaningful in a number of ways. First, it is significant because it empirically explains that urban farming can enhance the well-being of the elderly. Also, we hope this study can become a logical basis for future arguments emphasizing the importance of urban farming, as it provides statistical support for numerous studies that hypothesized the effect of urban farming on emotional health. Second, the correlation analysis between the main variables went beyond simply stating that participation in urban farming enhances the well-being of the elderly; it investigated the relationship of specific variables such as age, period of participation, and satisfaction with one's economic condition to psychological, social, and environmental well-being, and provided a framework for future research. Third, this study is meaningful in that the mediating effects of social and environmental well-being on the relationship between participation in urban farming and improved psychological well-being indicate clear pathways and processes for enhancing well-being and provides a new model of this phenomenon.

Like most other studies, this study has a few limitations. First, it only surveyed elderly persons from certain areas, including Gyeonggi Province and Busan, and did not reflect the opinions of all elderly persons in the country. Second, the scales used in this study were adjusted versions of existing scales for measuring well-being, and did not consider the unique characteristics of the environment of each respondent. Finally, the study did not concretize the lower-order variables that comprised psychological, social, and environmental well-being.

Despite the multiple effects of urban farming, the growth of this practice in Korea is inadequate compared to other developed countries. According to Park, Koo, Park, and Kwon [10], the greatest obstacles to the expansion of urban farming include lack of funds, lack of will to implement policy, and lack of interest from citizens. Government officials and citizens still have an undeveloped awareness of urban farming and this reflects the government's lack of resolution to expand urban farming. Therefore, there is a need for follow-up studies that can raise governments' and citizens' awareness regarding urban farming. If further empirical studies can address the abovementioned limitations of our current study, this can add legitimacy to the expansion of urban farming and spur the establishment of relevant laws and regulations and the provision of institutional support. We hope that this study becomes a basis for such developments. 


\section{REFERENCES}

[1] J. Heo and H. Kwon, "Participation in urban farming and evaluation of its multiple functions," The Seoul Institute, vol. 15, vol. 4, pp. 5364, December, 2014.

[2] D. Kim, "Surveys and research reports on urban farming: Concepts, origins, and development approaches based on various cases," Daegu Gyeongbuk Environment Research Center Soil and Freedom, Urban Farming Research Committee, 2004.

[3] H. Yeo et al., "Study of cases of design stereotyping to invigorate urban farming," Korea Design Knowledge Society, Design Knowledge Journal, vol. 24, pp. 41-50, October, 2012.

[4] S. Keum, "Riddle of green growth, invigoration of urban farming," Busan Development Institute, no. 74, 2010.

[5] J. Heo and T. Kim, "Evaluating the multiple functions of urban farming using nonparametric methods," Korean Association of Organic Agriculture, vol. 20, pp. 431-445, 2012.

[6] P. Won-jae et al., "Comparison of city-dweller and civil servant perceptions of urban farming," The Korean Institute of Landscape Architecture, Collection of Conference Papers August, 2012.

[7] Y. Lim, Y. Ko, H. Shin, and Y. Cho, "Special symposium: Koreans' happiness and mental health index: Mental health of koreans," Korean
Psychological Organization Collection of Papers from Yearly Symposium, 2010.

[8] C. L. M. Keyes, "The mental health continuum: From languishing to flourishing in life," Journal of Health and Social Behavior, vol. 43. pp. 207-222, June 2002.

[9] R. M. Baron and D. A. Kenny, "The moderator-mediator variable distinction in social psychological research: Conceptual, strategic, and statistical considerations," Journal of Personality and Social Psychology, 1986.

[10] J. Choi, "Urban farming for family-friendly local societies and recovery of a community lifestyle for families," Korea Family Resource Management Association, Collection of Conference Papers, 2009, pp. 41-51.

Min-Hwan Na is with Hankuk Academy of Foreign Studies Senior, - as a co-author of study on Korea's Climate Change Policy and Harmonious Development of Industrial Competitiveness, and Policy Efficiency.

Ji-Hye Yang is with Hankuk Academy of Foreign Studies Senior, as a co-author of study on Korea's Climate Change Policy and Harmonious Development of Industrial Competitiveness, and Policy Efficiency. 